\title{
Chemical composition of smectites formed in clastic sediments. Implications for the smectite-illite transformation
}

\author{
A. DRIEF AND F. NIETO* \\ Departamento de Mineralogía y Petrología, Instituto Andaluz de Ciencias de la Tierra, Universidad de Granada- \\ C.S.I.C. Av. Fuentenueva s/n, 18002 Granada, Spain
}

(Received 19 July 1999; revised 23 February 2000)

\begin{abstract}
AB STRACT: Analytical electron microscopy of representative smectites from soils and sediments revealed that $\mathrm{K}$ was present in significant proportions. It was the major interlayer cation in soils from pelitic rocks, continental and marine sediments, independent of their diagenetic grade. Sodium was predominant only in soils from basic rock. Fluvial sediments contained smectites with both kinds of interlayer compositions. The octahedral composition of each sample ranged widely, covering various fields of dioctahedral smectites. The most important trend was the substitution of $\mathrm{Al}$ by $\mathrm{Fe}$ and $\mathrm{Mg}$; the chemistry of each smectite particle was determined by the parent mineral from which it formed. The real interlayer composition has important implications for the diagenetic smectite-illite transformation. When considering a typical $\mathrm{K}$ content, the smectite-illite reaction, with chlorite and quartz as subproducts, needs only $0.21 \mathrm{~K}$ atoms. For more K-rich compositions, a reaction is possible without an external supply of $\mathrm{K}$.
\end{abstract}

KEYWORDS: smectite, AEM, clastic sediments, soil.

Dioctahedral smectites are abundant clay minerals in the Earth's surface. They occur widely due to the interface reaction between the constituents of the earth's surface and aqueous solutions, giving rise to more stable secondary minerals. Thus, they have been described as one of the constituents of soils and sediments. They are also found as weathering products of volcanic ash, tuff and other rocks, as hydrothermal products and as diagenetic products in ocean basins. Based primarily on their thermal and chemical properties, Grim \& Kulbicki (1961) pointed out the existence of two distinct varieties of Al-rich montmorillonites, namely the Cheto and Wyoming types. More recently, electron-beam techniques have revealed important details about the heterogeneity of smectites (Ramseyer \& Boles,

\footnotetext{
* E-mail: fnieto@goliat.ugr.es
}

1986; Bouchet et al., 1988; Altaner \& Grim, 1990; Singh \& Gilkes, 1991; Sánchez-Navas et al., 1998).

The interlayer composition of smectites is very important in the smectite-illite transition. This transition is a fundamental process which occurs during the diagenesis of all argillaceous sediments and shales and has been studied extensively (Nadeau et al., 1985; Yau et al., 1987; Ahn \& Peacor, 1989; Hansen \& Lindgreen, 1989; Inoue et al., 1990; Buatier et al., 1992; Nieto et al., 1996; Clauer et al., 1997). Hower et al. (1976) studied the mineralogical and chemical changes in cores of Oligocene-Miocene argillaceous sediments from the Gulf Coast and proposed the following reaction for the smectite-illite transition:

$$
\text { smectite }+\mathrm{Al}^{3+}+\mathrm{K}^{+}=\text {illite }+\mathrm{Si}^{4+}
$$

The reaction of smectite to illite, as implied by Hower et al. (1976), involves the retention of the basic structure of 2:1 layers with the fixation of $\mathrm{K}$ 
in the interlayer sites and the concomitant substitution of $\mathrm{Si}$ by $\mathrm{Al}$ in the tetrahedral sheet. The $\mathrm{K}$ and $\mathrm{Al}$ involved in the reaction are considered by these authors to be released by the dissolution of K-feldspar (and/or mica). Other authors supported this theory for the origin of $\mathrm{K}$ (e.g. Kirsimäe et al., 1999). As smectite is generally considered to be originally $\mathrm{Ca}$ - or $\mathrm{Na}$-saturated, a significant gain of $\mathrm{K}$ must occur. The evolution from $\mathrm{Na}$-Ca-smectite to $\mathrm{K}$-smectite was considered an important prior step in the diagenetic transformation of smectite into illite. Since illite differs from smectite mainly in the $\mathrm{Si} / \mathrm{Al}$ ratio and $\mathrm{K}$ content, the enrichment in $\mathrm{K}$ is one of the genetic problems of the development of a rock from sediments. However, smectites having $\mathrm{K}$ as the dominant interlayer cation have recently been reported as occurring in many sites, including Gulf Coast mudstones (Freed \& Peacor, 1992), Barbados accretionary wedge bentonites (Buatier et al., 1992), Nankai Trough bentonites (Masuda et al., 1996), altered mid-oceanic-ridge basalt (Shau \& Peacor, 1992), marine muds from the Mississippi Delta (Hover et al., 1995), and bentonite and associated sediments from Kaka Point, New Zealand (Li et al., 1997).

The aim of this study was to describe the chemistry of clastic-sediment-forming smectites belonging to different sedimentary environments and to compare their interlayer occupancy with Krich smectites previously reported by other authors in order to elucidate when, in their geological evolution, the smectites of clastic materials become K-rich.

\section{MATERIALS AND METHODS}

\section{Materials}

Five smectite-bearing materials were collected from different areas. They were chosen as representative of the different steps of the geological evolution of smectites from clastic materials (Table 1). Sample VS is a subvolcanic derived soil. The parent rock corresponds to small bodies (ophites) forming part of the Mesozoic basic magmatism in the external zones of the Betic Cordilleras, in the south of Spain (PortugalFerreira et al., 1995; Morata et al., 1997). The mineralogical composition of the parent rock, as determined in thin-section by optical microscopy, reveals the same mineral assemblage as in the soil, but lacking smectite. The soil developed on a quarry abandoned for more than twenty years. The position of the soil implies that the subvolcanic rock was its only source material. Sample MM corresponds to the soil horizon of the alteration profile of the garnet-rich mica-schist formation described by Velilla (1983). This formation is located in the Mulhacén group of the Sierra Nevada Complex (S. Spain) at $>2500 \mathrm{~m}$ and no other rock exists at a topographically higher level. Therefore, the garnet-rich mica-schist formation was the only possible source material of the soil. Sample CR was collected at $10 \mathrm{~m}$ depth under the water level in the Cubillas Reservoir (Granada Province). This dam is well known to be almost entirely silted up due to the large quantity of fluvial input. This sample is considered as representative of fluvial transported material.

TABLE 1. Bulk mineralogical composition of the smectite-bearing samples based on XRD results.

\begin{tabular}{|c|c|c|c|c|c|c|c|c|}
\hline \multirow[t]{2}{*}{ Smectite-bearing material } & \multirow[t]{2}{*}{ Sample } & \multicolumn{7}{|c|}{ Bulk mineralogy } \\
\hline & & Phy & Qtz & $\mathrm{Fd}$ & $\mathrm{Cal}$ & Dol & Py & $\mathrm{Ol}$ \\
\hline Subvolcanic derived soil & VS & M & $*$ & $P$ & * & * & $P$ & $\mathrm{P}$ \\
\hline Mica-shist derived soil & MM & M & A & $\mathrm{T}$ & * & $*$ & * & $*$ \\
\hline Cubillas-reservoir fluvial input & $\mathrm{CR}$ & $\mathrm{M}$ & $\mathrm{A}$ & $*$ & A & A & * & $*$ \\
\hline Continental sediments $(2 \mathrm{~m}$ depth $)$ & $\mathrm{GC}-2$ & $\mathrm{M}$ & $\mathrm{A}$ & A & $\mathrm{A}$ & $\mathrm{A}$ & * & $*$ \\
\hline Continental-sediment derived soil & GC-0 & $\mathrm{M}$ & $\mathrm{A}$ & $\mathrm{A}$ & A & $\mathrm{A}$ & * & * \\
\hline
\end{tabular}

Phy = phyllosilicates, $\mathrm{Qtz}=$ quartz, $\mathrm{Fd}=$ feldspars, $\mathrm{Cal}=$ calcite, $\mathrm{Dol}=$ dolomite, $\mathrm{Py}=$ pyroxenes, $\mathrm{Ol}=$ olivine $\mathrm{M}=$ major, ${ }^{*}=$ absent, $\mathrm{P}=$ present, $\mathrm{T}=$ traces 
Sample GC-2 corresponds to continental marls excavated during the building works of the Engineering School in Granada. It was collected at $2 \mathrm{~m}$ depth under the present surface, from fresh material reached during the works. Sample GC-0 is the soil that developed over these continental marls.

The compositions of four K-rich marine smectites reported in the literature (Table 2) have been used to compare their interlayer occupancy with those of the present study. Lower Pliocene sediments from the Alboran basin consist mainly of biogenic and detrital components, with a minor contribution of neoformed mineral phases (Martínez-Ruiz et al., 1999). The bentonite described by Li et al. (1997) corresponds to a bentonitic altered tuff, commonly containing crystal clasts near the base of the section, and relict 'heulanditized' glass shards. The bentonite was collected near the top of the Etalian Stage, Middle Triassic, $\sim 700 \mathrm{~m}$ north of Kaka Point promontory. The smectite described by López-Galindo et al. (1998) occurred in the Antarctic Tertiary sediments. These sediments contained minerals of detrital origin such as quartz, feldspar, pyroxene, chlorite and mica, as well as smectite and amorphous matter. Calcite, aragonite, ankerite, amphibole and other secondary phases such as pyrite, halite, gypsum and zeolites were also found. Finally, smectite occurring in marls, as described by Nieto et al. (1996), belongs to Mesozoic-Cenozoic sediments in the BasqueCantabrian Basin, Spain. These sediments were affected by diagenesis at different grades. The smectite-bearing sample was collected from the top of the sequence. Overall, these four sets of samples represent different marine environments ranging from detrital smectites with no transformation in the sedimentary basin to authigenesis during early diagenetic processes, also including the beginning of burial diagenesis.

\section{$X$-ray diffraction}

For bulk mineralogy, samples were air dried and homogenized by grinding in an agate mortar. For clay mineral analyses, the carbonate fraction was removed (CR, GC-0 and GC-2 samples) using acetic acid. The reaction started at a very low concentration $(0.1 \mathrm{~N})$, and then increased to $1 \mathrm{~N}$, depending on the amount of carbonate in the sample. The $<2 \mu \mathrm{m}$ fraction was separated by centrifugation. The clay fraction was smeared on glass slides and air dried in atmospheric conditions. The slides were then saturated with ethylene glycol at $80^{\circ} \mathrm{C}$ for $24 \mathrm{~h}$ to ensure maximum saturation and heated at $550^{\circ} \mathrm{C}$ for $1 \mathrm{~h}$. X-ray diffraction patterns were obtained using a Philips PW-1710 diffractometer (with a graphite monochromater and automatic slit) operating at $40 \mathrm{kV}$ and $40 \mathrm{~mA}$, with a scanning speed of $2^{\circ} 2 \theta /$ min using $\mathrm{Cu}-\mathrm{K} \alpha$ radiation. The relative proportions of clay minerals were calculated after correction for the effect of the automatic slit.

\section{Analytical electron microscopy}

Quantitative analyses were performed with a Philips CM20 device equipped with an EDAX solid-state, EDX detector (ultrathin window) in the 'Centro de Instrumentación Científica' of Granada University (CIC). The microscope was operated at $200 \mathrm{kV}$ in TEM mode for the identification and selection of different grains. Scanning TEM mode was used for quantitative analyses of thin edges of particles using a $4 \mathrm{~nm}$ diameter beam and $20 \times 100 \mathrm{~nm}$ scanning area. Smectite grains were identified by their chemical composition, which in all the studied samples was very different from detrital mica (muscovitic composition). As all the studied soils and sediments are unaffected by diagenetic alteration, illite was absent. Muscovite,

TABLE 2. Smectite-bearing marine sediments with their respective references.

\begin{tabular}{lll}
\hline Smectite-bearing material & \multicolumn{1}{c}{ Site } & \multicolumn{1}{c}{ Authors } \\
\hline Lower Pliocene sediments & Hole 976B (ODP Leg 161), Alboran Basin & Martínez-Ruiz et al. (1999) \\
Bentonites and associated rocks & New Zealand & Li et al. (1997) \\
Antarctic Tertiary sediments & Sondage 270, Mar de Ross, Antarctic & Lopez-Galindo et al. (1998) \\
Basque Cantabrian Basin marls & North of Spain & Nieto et al. (1996) \\
\hline
\end{tabular}


albite, biotite, spessartine, olivine and titanite were used as standards to calculate K-factors by the thin-film method of Lorimer \& Cliff (1976). Errors $(2 \sigma)$, expressed as a percentage of the atomic proportions for the analysed elements, were $6(\mathrm{Na}), 3(\mathrm{Mg}), 2(\mathrm{Al}), 4(\mathrm{~K}), 4(\mathrm{Ca}), 5(\mathrm{Ti}), 3$ $(\mathrm{Mn})$ and $3(\mathrm{Fe})$. A portion of the bulk material, with no previous treatment, was also dispersed in distilled water and then deposited on collodion and carbon films coated on copper grids, then air-dried at room temperature. Due to the overlapping of the $L$ band of $\mathrm{Cu}$ and the $K$ band of $\mathrm{Na}$, gold grids were used to analyse $\mathrm{Na}$ and to evaluate how copper grids can affect the analysis of $\mathrm{Na}$ smectites and to quantify the interlayer occupancy for further comparison with K-smectites. A long counting time $(200 \mathrm{~s})$ was used in both types of analyses (copper and gold grids) since no loss of alkalis was observed during the analysis time. All the $\mathrm{Fe}$ was assumed to be in ferric form. Even if some $\mathrm{Mg}$ is located in the interlayer sites, no attempt to ascertain its distribution has been carried out and its overall content has been assigned to the octahedral position. Because the real excess over 2 of the octahedral cation population is not known, we are unable to define a valid criterion of this distribution.

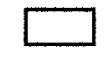

smectite

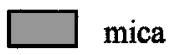

chlorite and kaolinite
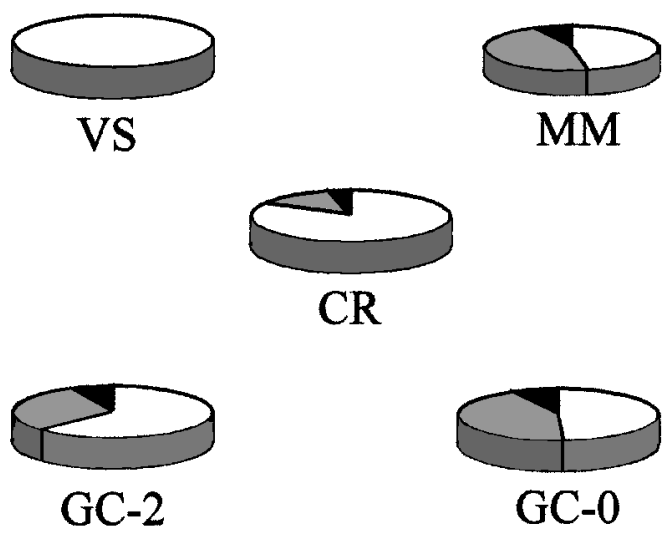

FIG. 1. Semi-quantitative analyses of clay fraction based on XRD study.

\section{RESULTS}

\section{$X$-ray diffraction data}

The bulk mineralogical composition of the studied samples, obtained by XRD, is reported in Table 1. Semi-quantitative analyses of the clay fraction are given in Fig. 1. Smectite was the principal clay mineral phase present in all the studied samples, with significant amounts of mica, kaolinite and chlorite, except for the VS sample which contained smectite exclusively. The XRD patterns of the clay fraction after various treatments are presented in Fig. 2. The GC-0 and GC-2 smectites showed a 14-14.5 moved to $\sim 17 \AA$ after treatment with ethylene glycol, and to $\sim 10 \AA$ after heating at $550^{\circ} \mathrm{C}$ for $1 \mathrm{~h}$. The same behaviour was observed in the rest of the samples. However, a peak at 13.75 and $13.93 \AA$ remained even after heating at $550^{\circ} \mathrm{C}$ for $1 \mathrm{~h}$ in the GC-0 and GC-2 samples, respectively, indicating the presence of chlorite.

\section{Analytical electron microscope data}

The structural formulae of smectites calculated from AEM analyses on the basis of 11 oxygens are listed in Table 3. These formulae show that both the $\mathrm{Si}$ and $\mathrm{Al}$ contents vary widely, especially in the subvolcanic derived soil (VS) and the mica-schist derived soil (MM). Silica ranges between 3.23 and 3.86 for the VS smectites and between 3.30 and 3.90 for the MM smectites. The ranges for $\mathrm{Mg}$ and $\mathrm{Fe}$ are also wide, suggesting that different types of smectites are present, and both can exceed 0.30 a.p.f.u. (atoms per formula unit) in all the analysed samples. The smectite of fluvial input (CR) showed the most homogeneous composition. Regarding the interlayer cations, the analyses show that the smectites have a significant amount of K. A low $\mathrm{Na}$ content is not detected due to the overlapping of the $L$ band of $\mathrm{Cu}$ and the $K$ band of Na. Therefore, analyses with gold grids were also carried out (Table 4) to quantify more precisely the $\mathrm{Na}$ content and to establish a relationship between interlayer cations. The analyses of smectites show no systematic differences from those obtained with copper grids, with the exception of the low Na contents. This element was detected only in two samples VS and CR, when it was the dominant interlayer cation in the former. All analysed smectites in the MM, GC-0 and GC-2 samples are $\mathrm{Na}$ free. 

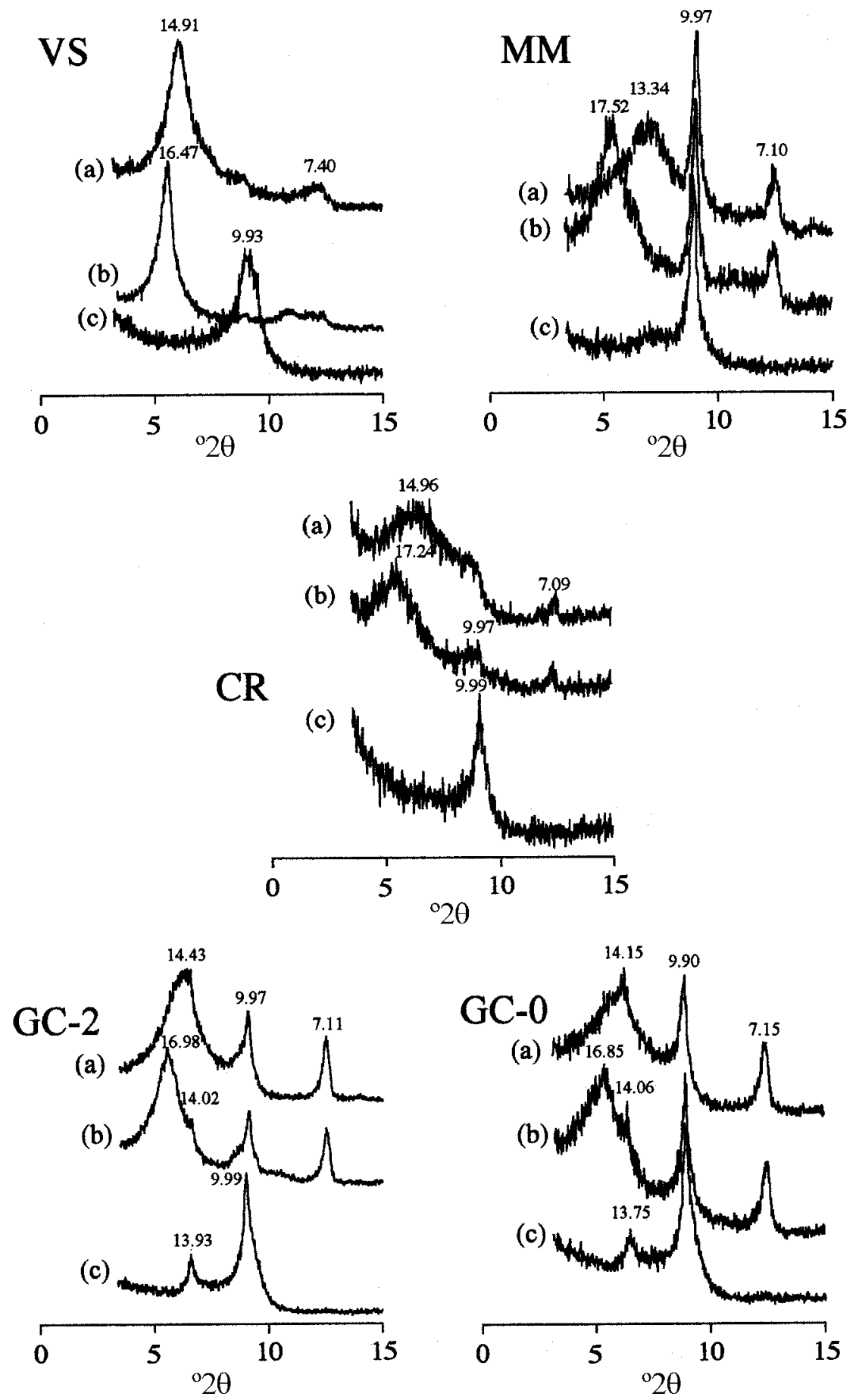

FIG. 2. XRD patterns of the oriented clay fraction. (a) air-dried sample; (b) glycolated sample; and (c) heated to $550^{\circ} \mathrm{C}$. Note that the use of an automatic slit proportionally reduces the intensity of lower-angle peaks. Spacings in $\AA$ 


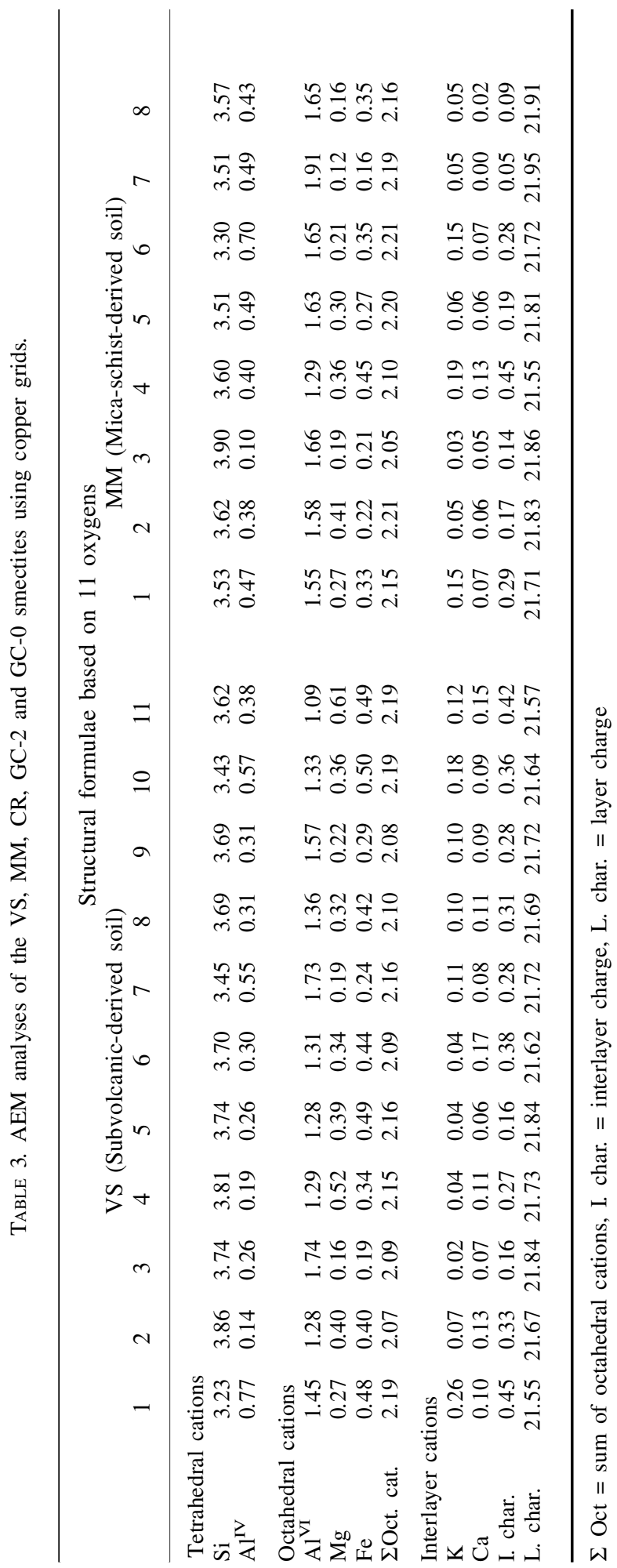




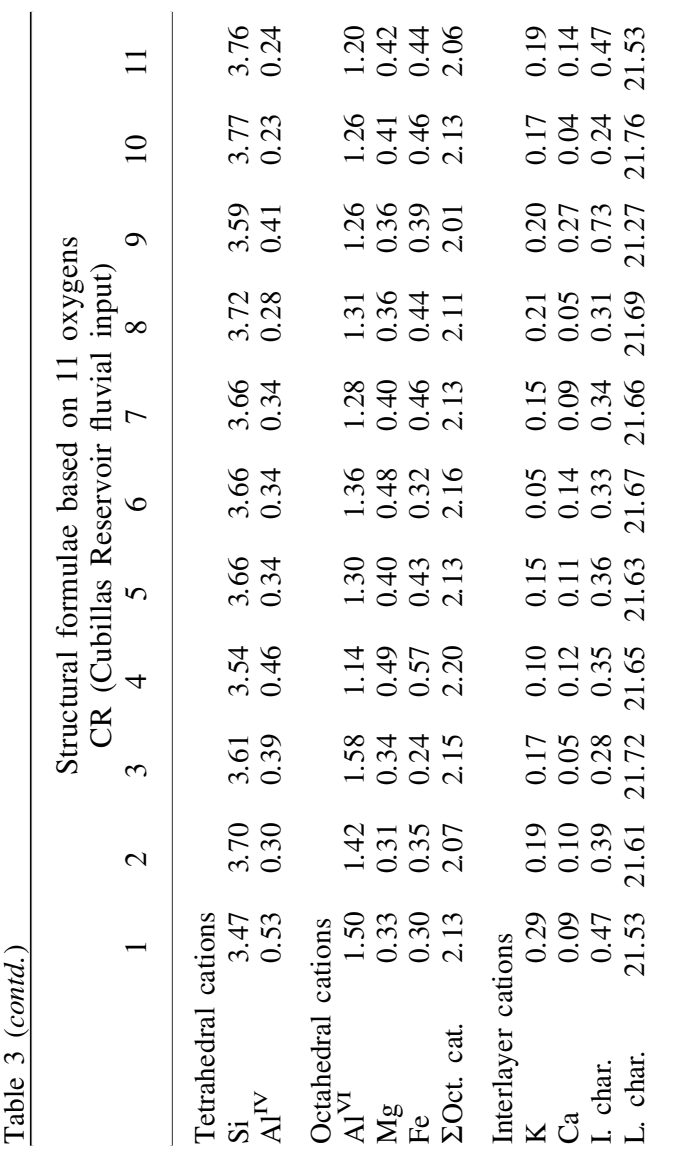

\begin{tabular}{|c|c|c|c|}
\hline$a$ & $\begin{array}{l}\text { Tै }{ }^{\infty} \\
\text { ri }\end{array}$ & 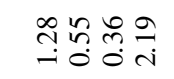 & 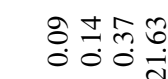 \\
\hline & $\begin{array}{l}\infty \\
\infty \\
\text { ri }\end{array}$ & 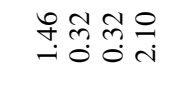 & 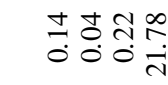 \\
\hline 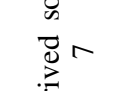 & ñ & 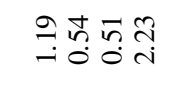 & 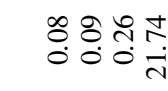 \\
\hline$\frac{\bar{d}}{\stackrel{0}{\frac{1}{0}}} 0$ & $\stackrel{\infty}{\stackrel{2}{f}}$ & 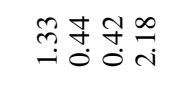 & 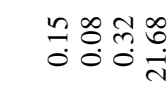 \\
\hline$\stackrel{\Xi}{\Xi_{\mathscr{D}}} n$ & mi & 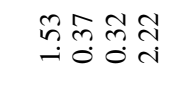 & 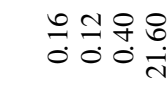 \\
\hline 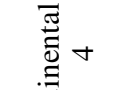 & $\begin{array}{ll}\stackrel{\nabla}{\pi} & \pi \\
\dot{0} & 0\end{array}$ & Fษ் & $\begin{array}{l}\because g \bar{\theta} \\
\dot{0} \dot{0}\end{array}$ \\
\hline$\overbrace{0} \underbrace{0}_{0}$ & 요요 & 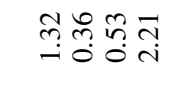 & $\bar{N}=\stackrel{m}{\circ} \frac{\hat{n}}{0}$ \\
\hline 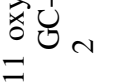 & in & 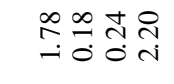 & m̊̊ \\
\hline $\begin{array}{l}\tilde{0} \\
\text { ठ }\end{array}$ & min & 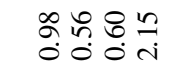 & 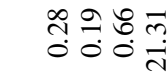 \\
\hline 冚 & $\begin{array}{l}\text { R ? } \\
\text { ri }\end{array}$ & 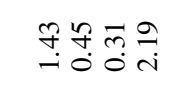 & $\begin{array}{l}\text { I } 5 \frac{\infty}{0} \frac{\infty}{0} \\
00\end{array}$ \\
\hline$\overparen{E}$ & ñ & 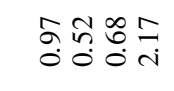 & 光 \\
\hline 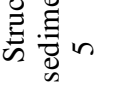 & $\begin{array}{l}\text { mî } \\
\text { mio }\end{array}$ & 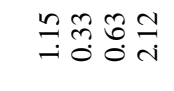 & $\begin{array}{l}m=\stackrel{n}{n} \\
0 \\
0\end{array}$ \\
\hline$\stackrel{\widetilde{\Xi}}{\stackrel{\Xi}{\Xi}}+$ & min & 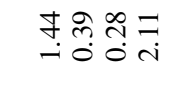 & 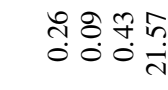 \\
\hline 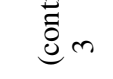 & $\begin{array}{l}\infty \\
+ \\
\dot{1}\end{array}$ & 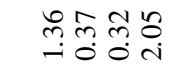 & 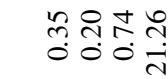 \\
\hline$\bigcup_{0}^{1} N$ & $\begin{array}{l}8 \text { 웅 } \\
\text { rio }\end{array}$ & 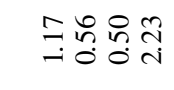 & 웜 \\
\hline- & 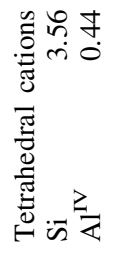 & 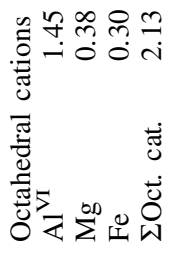 & 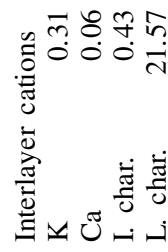 \\
\hline
\end{tabular}




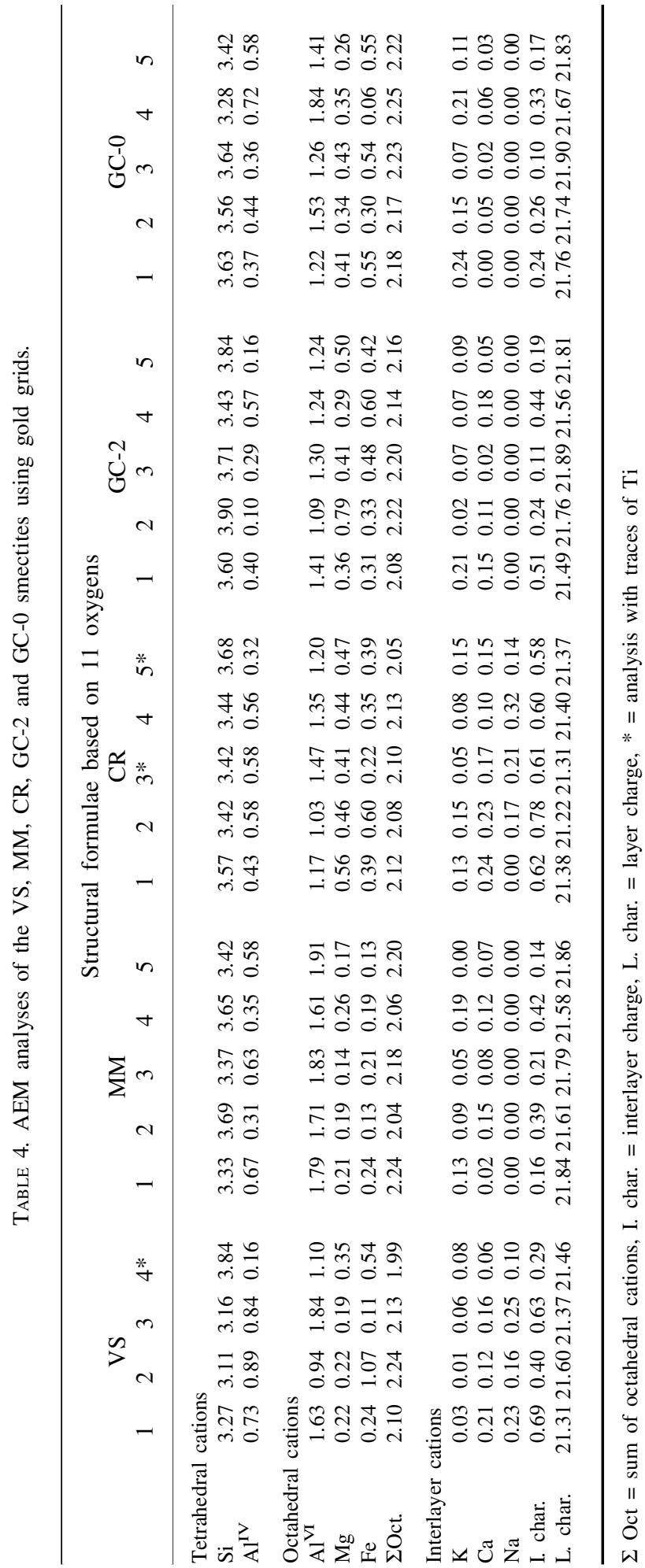


The compositional variation of smectites is represented in Fig. 3. The substitution of $\mathrm{Al}^{\mathrm{VI}}$ by $\mathrm{Fe}$ in the octahedral sites varies widely, providing a well-defined inverse relationship between these two elements (Fig. 3a). A similar negative relationship is also observed between $\mathrm{Al}^{\mathrm{VI}}$ and $\mathrm{Mg}$ (Fig. 3b). The smectites from the VS sample vary widely and the MM smectites are richer in Al than the rest of the samples. No significant relationship was found between $\mathrm{Si}$ and $\mathrm{Mg}$ or between $\mathrm{Fe}$ and $\mathrm{Si}$ (not shown). Nevertheless, there is a poorly defined positive relationship between $\mathrm{Fe}$ and $\mathrm{Mg}$, although it is not clear in the continental sediment smectite (GC-2). Finally, there is a weakly defined negative relationship between $\mathrm{Al}^{\text {tot }}$ and $\mathrm{Si}$.

A plot of the octahedral composition of smectite in an AlMg-AlAl-AlFe ternary system (Güven, 1988) shows that the smectite composition for each sample does not fall within a single field assigned to a particular type, but to clusters overlapping different kinds of dioctahedral smectites (Fig. 4). The VS smectite reveals two different clusters. The first one plots between Fe-rich montmorillonite and Fe-rich beidellite and the
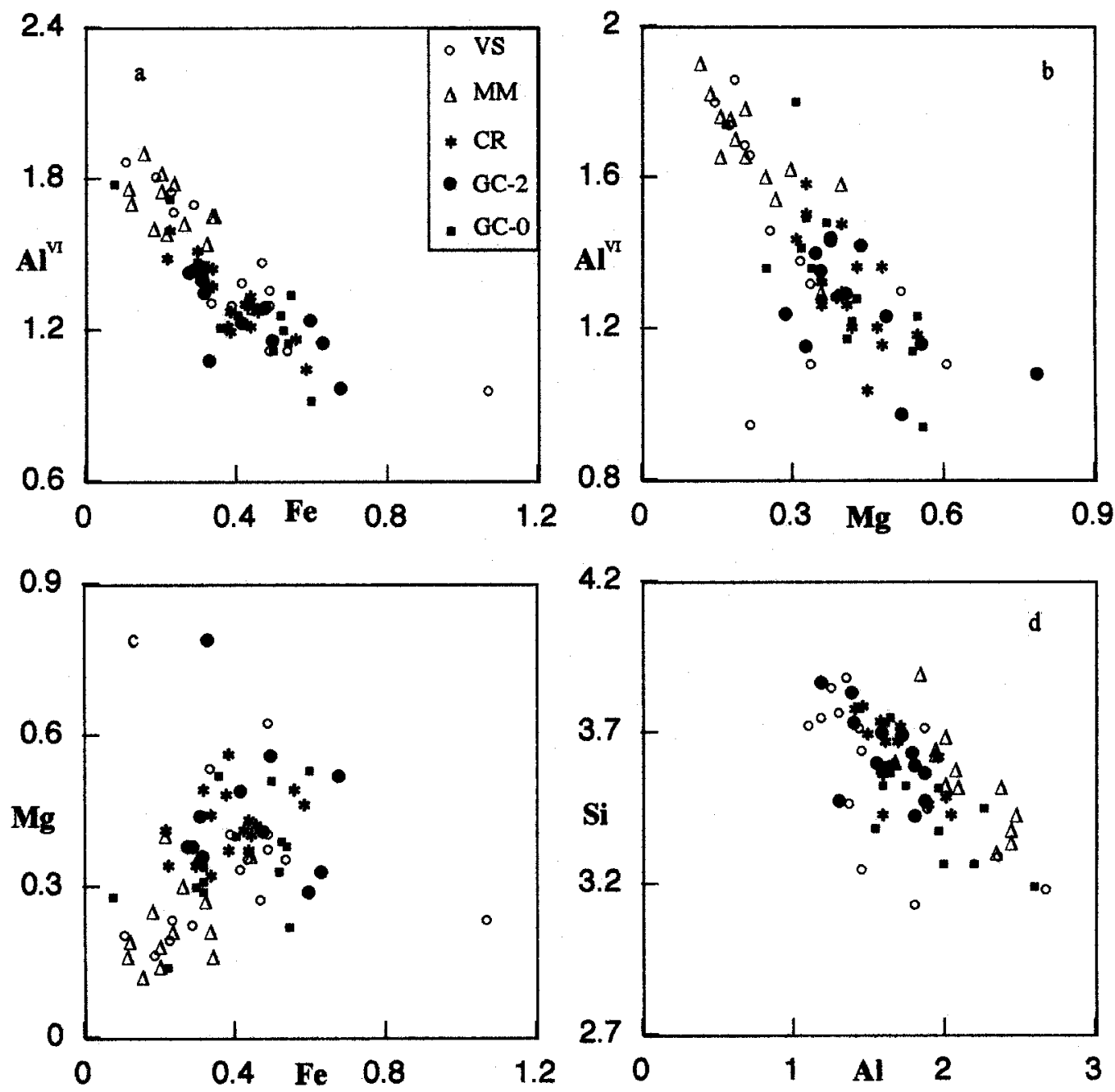

FIG. 3. Compositional variation of the smectites after normalizing to $10 \mathrm{O}$ and $2(\mathrm{OH})$. The AEM analyses are those of Tables 3 and 4 . 
second in a trend between Wyoming-type montmorillonite and beidellite. The MM smectite composition is more aluminous and plots mainly between beidellite and Fe-rich beidellite. Fluvialinput smectites (CR) plot mainly in the field of $\mathrm{Fe}$ rich montmorillonite. Two distinct clusters can be identified for GC-0 and GC-2 smectites; one of them falls in the Fe-rich montmorillonite field and the other one in a zone of intermediate composition between Cheto-type, Wyoming-type, Fe-rich beidellite and Fe-rich montmorillonite. In general, the scattering of the analyses for all samples approaches the overall field of dioctahedralsmectite composition.

The interlayer cations ( $\mathrm{Na}, \mathrm{K}$ and $\mathrm{Ca}$ ), determined using gold grids, were plotted in the Ca-K$\mathrm{Na}$ ternary system (Fig. 5a). They show a wide range of variation. In the smectite VS, Na is the dominant interlayer cation, whereas in CR smectites different populations coexist; from $\mathrm{Na}$ free to $\mathrm{Na}$ dominant. The interlayer composition of marine samples in the literature (Table 2) were also plotted (Fig. 5b). They show different proportions of $\mathrm{Ca}$

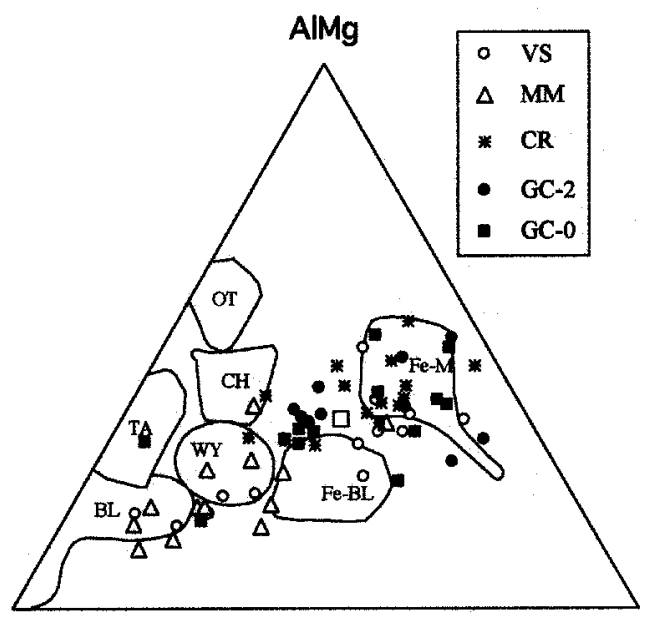

\section{AlA|}

AlFe

FIG. 4. Projection of the smectite composition in the ternary system $\mathrm{AlMg}-\mathrm{AlAl}-\mathrm{AlFe}$ as proposed by Güven (1988). OT = Otay montmorillonite, $\mathrm{CH}=$ Chambers montmorillonite, $\mathrm{TA}=$ Tatatilla montmorillonite, $\mathrm{WY}=$ Wyoming montmorillonite, $\mathrm{BL}=$ beidellite, $\mathrm{Fe}-\mathrm{BL}=\mathrm{Fe}$-rich beidellite, $\mathrm{Fe}-\mathrm{M}=\mathrm{Fe}$-rich montmorillonite. The AEM analyses are those of Tables 3 and 4. The open square shows the smectite composition proposed in equation 2 (see text for explanation). and $\mathrm{Na}$, but $\mathrm{K}$ is clearly the dominant interlayer cation, regardless of whether they are diagenetically altered or not.

\section{DISCUSSION AND CONCLUSIONS}

Prior to the development of in situ analysis techniques, data from the chemical composition of minerals were derived exclusively from whole rocks using monomineral samples or from assemblages in which the separation of minerals was possible. The use of the electron microprobe (EMPA) allowed the differences between rock-forming minerals and equivalent minerals previously analysed on separate samples to be studied. Nevertheless, the small size

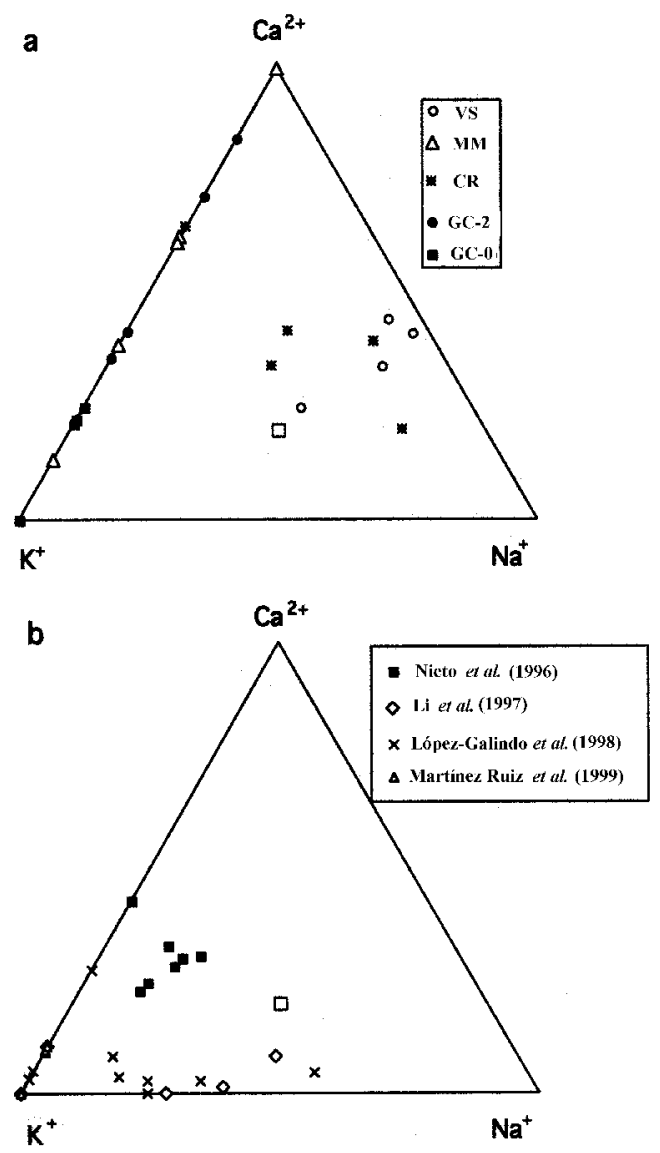

FIG. 5. Plot of the interlayer composition of smectites in the Ca-K-Na ternary system. (a) smectites of the present study; (b) the smectites reported in Table 2. The open square shows the smectite composition proposed in equation 2 . 
of smectites and their defective nature in sediments made such analyses impossible. Therefore, knowledge concerning the real composition of smectites in soils and sediments was not obtained and it was assumed that the typical smectite composition was that of materials in which they were the only phase or easily separated. Recently, AEM analyses have demonstrated that smectites (coexisting with other minerals) forming sediments or sedimentary rocks can also be analysed.

These smectites play an important role in the geological cycle. They are the basic material for the smectite-illite transformation during the diagenesis of sedimentary materials giving rise to illite-bearing sedimentary rocks. Illite is subsequently enriched in $\mathrm{K}$ and leads to muscovite during metamorphic alteration of the rock. This is why numerous clay mineralogical studies gave such great importance to the smectite-illite transformation through I-S mixed-layers in both natural (e.g. Amouric \& Olives, 1991; Buatier et al., 1992; Nieto et al., 1996; Li et al., 1997; Lindgreen \& Hansen, 1991) and experimental (e.g. Huang et al., 1993) studies.

All the models developed for the smectite-illite transformation assumed that smectites were originally Ca-Na-rich and K-poor. The compositions used were based on pure smectite material, and therefore smectite enrichment in $\mathrm{K}$ and a concomitant loss of $\mathrm{Ca}$ and $\mathrm{Na}$ were considered as the first step in the diagenetic transformation of smectite into illite. $\mathrm{K}$-feldspar and detrital mica were considered as the source of the necessary K. Recent studies on marine smectites (Table 2) showed that $\mathrm{K}$ was the major interlayer cation (Fig. 5b). The smectites of continental sediments analysed in this paper (GC-2 and GC-0) showed no differences from their marine equivalents (Fig. 5a). Therefore, the K-enrichment of smectite must have occurred before diagenesis. Because exchangeable $\mathrm{K}$ should be substituted by $\mathrm{Na}$ during marine transport, a significant amount of this $\mathrm{K}$ is expected to be non-exchangeable in nature.

Regarding the chemistry of the smectites, their composition is partially dependent on the parent rock. In the soils studied, the smectites derived from K-poor rocks such as the VS subvolcanic soil have $\mathrm{Na}$ and $\mathrm{Ca}$ as the major interlayer cations. None-the-less, some analyses showed significant amounts of K. Smectites derived from K-rich material (MM mica-schist soil) have $\mathrm{K}$ as the dominant interlayer cation and are free of $\mathrm{Na}$ (Fig. 5a). Smectites from fluvial input CR are more heterogeneous in their interlayer composition due to the convergence of several kinds of inputs. These smectites may be Na-free and K-rich as in the MM, GC-2 and GC-0 samples or Na-Ca-rich. Nevertheless, they always contain a significant amount of K (Fig. 5a).

A wide range of variation in both octahedral (Figs 3,4) and tetrahedral sheets (Tables 3,4) is exhibited by all samples. There are some relationships between the smectite composition and the parent material. The MM smectites (mica-schist derived soil) are richer in $\mathrm{Al}$, whereas VS smectites (subvolcanic derived soil) are richer in $\mathrm{Mg}$ and $\mathrm{Fe}$. However, the range of variation of a given sample may overlap that of all the samples. A plot of octahedral cations in the AlMg-AlAl-AlFe ternary system show that the octahedral composition does not plot within a single field and analyses of a sample can range between beidellite and Fe-rich montmorillonite passing through Wyoming-type, Cheto type and Fe-rich beidellite (Fig. 4). This means that the composition of each smectite crystal depends not only on the parent rock but also on the particular grain from which it originated. In spite of this wide range of variation, a compositional field of dioctahedral smectites, which always combines montmorillonitic, beidellitic and nontronitic substitutions in different proportions, is well defined. The main variation in this field is that of $\mathrm{Al}^{\mathrm{VI}} v s$. Fe and $\mathrm{Mg}$ (Figs 3 and 4), which is probably due to aluminous vs. ferromagnesian parents minerals.

The octahedral compositions of the smectites analysed do not plot within a single field corresponding to just one type of smectite such as those proposed by Güven (1988). This is probably due to the genetic origin of the smectites used to define the fields of this ternary system. These fields have no significance for clastic-sediment-forming smectites because they are a result of genetic rather than crystal-chemical factors (Fig. 4). There is a significant difference in the octahedral composition of clastic-sediment-forming smectites in comparison with those previously assumed in theoretical models or used in laboratory experiments. The differences presented in this paper between the actual composition of clastic-sediment-forming smectites and that previously assumed by theoretical and experimental models for the smectite-illite transformation have important implications for this diagenetic process.

Several models have been proposed to explain the smectite-to-illite transformation, all of them 
assuming that the Ca-Na-smectite transformation into K-smectite is necessary. Nevertheless, significant amounts of $\mathrm{K}$ concentrate in the interlayer sites of clastic-sediment-forming smectites before undergoing diagenesis (Tables 3,4). Therefore, the $\mathrm{K}$ necessary for the illite diagenetic formation is lower than previously assumed in the literature. As illite has a higher content of $\mathrm{K}$ than smectite, it is only logical to assume that a significant amount of $\mathrm{K}$ must be incorporated into the interlayer site of smectite to produce illite. However, some of the $\mathrm{Al}$ and $\mathrm{Si}$ from smectite, together with $\mathrm{Fe}$ and $\mathrm{Mg}$, form chlorite during the smectite-illite transformation (Lee et al., 1985). The genesis of chlorite from trioctahedral smectite in a similar way to the genesis of illite from dioctahedral smectite is not possible in clastic sediments. This type of origin for chlorite has been studied extensively in volcanic rocks and volcanoclastic sediments. A well-defined evolution from smectite to chlorite through corrensite and smectite/corrensite mixed-layers has been established (e.g. Inoue \& Utada, 1991; Shau et al., 1991). Nevertheless, trioctahedral smectites are absent from all the studied soils and sediments, including the subvolcanic-derived soil (Tables 3,4). Therefore, the dioctahedral smectites are the only source of the $\mathrm{Mg}$ and $\mathrm{Fe}$ required for the genesis of chlorite. A tentative reaction for the origin of both illite and chlorite from a typical composition of smectite similar to that of the present study (see open square in Figs 4 and 5) may be written as follows:

2.41 smectite $+0.21 \mathrm{~K}^{+}=1$ illite +0.35 chlorite + $4.95 \mathrm{Si}+0.30 \mathrm{Na}+0.24 \mathrm{Ca}(2)$

with: smectite $=\left(\mathrm{Si}_{3.80} \mathrm{Al}_{0.20}\right) \mathrm{O}_{10}$ $\left(\mathrm{Al}_{1.30} \mathrm{Mg}_{0.35} \mathrm{Fe}_{0.35}\right) \mathrm{K}_{0.20} \mathrm{Na}_{0.15} \mathrm{Ca}_{0.10}(\mathrm{OH})_{2}$; illite = $\left(\mathrm{Si}_{3.30} \mathrm{Al}_{0.70}\right) \mathrm{O}_{10}\left(\mathrm{Al}_{1.93} \mathrm{Mg}_{0.04} \mathrm{Fe}_{0.04}\right) \mathrm{K}_{0.70} \mathrm{Na}_{0.06}$; and $\mathrm{chlorite}=\left(\mathrm{S} \mathrm{i}_{2.60} \mathrm{Al}_{1.40}\right) \mathrm{O}_{10}$ $\left(\mathrm{Al}_{1.40} \mathrm{Mg}_{2.30} \mathrm{Fe}_{2.30}\right)(\mathrm{OH})_{8}$.

The smectite composition has been chosen as representative of the analysed smectites (see open square in Figs 4 and 5). The composition of illite is a typical one in low-temperature rocks (e.g. Środoń et al., 1986) and falls perfectly in the compositional field recently defined for illite by the nomenclature commission of IMA (Rieder et al., 1999). For Fe, 0.02 atoms have been considered as $\mathrm{Fe}^{3+}$. The resulting ratio between mica and chlorite is in accordance with those frequently observed in very low-grade shales, slates and phyllites. The proposed reaction requires input of less than a third part of the $\mathrm{K}$ content of illite $\left(0.21 \mathrm{~K}^{+}\right.$per formula unit) and a concomitant substantial loss of $\mathrm{Si}$ along with $\mathrm{Ca}$ and Na. These may be consumed, respectively, during the authigenesis of quartz, albite, paragonite and calcite that are also frequent minerals in this kind of rock. The system is considered closed for $\mathrm{Al}, \mathrm{Fe}$ and $\mathrm{Mg}$. The effect of $\mathrm{K}$ activity in the illitization process is well documented. However, the meaning of the proposed reaction is that $\mathrm{K}$ enrichment of smectite necessary to produce illite during diagenesis is less than that assumed previously and, therefore, an external supply of $\mathrm{K}$ may not be an absolute condition for the development of mature micas.

\section{ACKNOWLEDGMENTS}

We wish to thank F. Martínez-Ruiz for her useful comments and information about the data presented in her recent paper. The diving experience of A. RuizEsteban and F. Alonso-Aragón enabled them to obtain for us the subaquatic sample from the Cubillas Reservoir. D. Morata informed us of the existence of the abandoned quarry of subvolcanic rock and provided us with all the relevant geological information. $\mathrm{N}$. Velilla collected the mica-schist sample. We also acknowledge Dr D.R. Peacor for conversations, formal and informal, which gave us the idea for this research. We thank the referees F. Elsass and P.H. Nadeau for their critical review of the manuscript. Assistance from M.M. Abad-Ortega (AEM) and P. Sánchez-Gomez (XRD) was fundamental for the present work. Financial support was supplied by Research Project $n^{\circ}$ PB96-1383 of the Spanish Ministry of Education and Research Group RNM0179 of the Junta de Andalucía. We are grateful to C. Laurin for improving the English.

\section{REFERENCES}

Ahn J.H. \& Peacor D.R. (1989) Illite/smectite from Gulf Coast shales: a reappraisal of transmission electron microscope images. Clays Clay Miner. 37, 542-546.

Altaner S.P. \& Grim R.E. (1990) Mineralogy, chemistry and diagenesis of tuffs in the Sucker Greek formation (Miocene), Eastern Oregon. Clays Clay Miner. 38, $561-572$.

Amouric M. \& Olives J. (1991) Illitization of smectite as seen by high-resolution transmission electron microscopy. Eur. J. Mineral. 3, 831-835.

Bouchet A., Proust D., Meunier A. \& Beaufort D. (1988) High-charge to low-charge smectites reaction in hydrothermal alteration processes. Clay Miner. 23, $133-146$.

Buatier M., Peacor D.R. \& O' Neil J.R. (1992) Smectite- 
illite transition in Barbados accretionary wedge sediments: TEM and AEM evidence for a dissolution/crystallization origin at low temperature. Clays Clay Miner. 40, 65-80.

Clauer N., Środoń J., Francu J. \& Šucha V. (1997) K-Ar dating of illite fundamental particles separated from illite-smectite. Clay Miner. 32, 181-196.

Freed R.L. \& Peacor D.R. (1992) Diagenesis and the formation of authigenic illite-rich $\mathrm{I} / \mathrm{S}$ crystals in the Gulf Coast shales: TEM study of clay separates. $J$. Sed. Pet. 62, 220-234.

Grim R.E. \& Kulbicki G. (1961) Montmorillonite: high temperature reactions and classification. Am. Miner. 46, $1329-1369$.

Güven N. (1988) Smectite. Pp. $497-559$ in: Hydrous Phyllosilicates (S.W. Bailey, editor). Reviews in Mineralogy, 19. Mineralogical Society of America, Washington D.C., USA.

Hansen P.L. \& Lindgreen H. (1989) Mixed-layer illitesmectite diagenesis in Upper Jurassic claystones from the north Sea and onshore Denmark. Clay Miner. 24, $197-213$.

Hover V.C., Walter L.M., Peacor D.R. \& Martini A.M. (1995) K-uptake by smectite during early marine diagenesis in brackish and hypersaline depositional environments (abstract). 32nd Clay Miner. Soc. Annual Meeting Program and Abstracts. p. 61.

Hower J., Eslinger E.V., Hower M.E. \& Perry E.A. (1976) Mechanism of burial metamorphism of argillaceous sediments: 1 . Mineralogical and chemical evidence. Geol. Soc. Am. Bull. 87, 725 -737.

Huang W.-L., Longo J.M. \& Pevear D.R. (1993) An experimentally derived kinetic model for smectiteto-illite conversion and its use as a geothermometer. Clays Clay Miner. 41, 162-177.

Inoue A., Watanabe T., Kohyama N. \& Brusewitz A.M. (1990) Characterization of illitization of smectite in bentonite beds at Kinekulle, Sweden. Clays Clay Miner. 38, $241-249$.

Inoue A. \& Utada M. (1991) Smectite-to-chlorite transformation in thermally metamorphosed volcanoclastic rocks in the Kamikita Area, Northern Honshu, Japan. Am. Miner. 76, 628-640.

Kirsimäe K., Jørgensen P. \& Kalm V. (1999) Lowtemperature diagenetic illite-smectite in Lower Cambrian clays in North Estonia. Clay Miner. 34, $151-163$.

Lee J.H., Ahn J.H. \& Peacor D.R. (1985) Textures in layered silicates: progessive changes through diagenesis and low-temperature metamorphism. J. Sed. Pet. 55, $532-540$.

Li G., Peacor D.R. \& Coombs D.S. (1997) Transformation of smectite to illite in bentonite and associated sediments from Kaka Point, New Zealand: Contrast in rate and mechanism. Clays Clay Miner. 45, 54-67.

Lindgreen H. \& Hansen P.L. (1991) Ordering of illite- smectite in Upper Jurassic claystones from the north Sea. Clay Miner. 26, $105-125$.

López-Galindo A., Marinoni L., Ben Aboud A. \& Setti M. (1998) Morfología, fábrica y quimismo en esmectitas de los sondeos Ciros-1, 270 y 274 (Mar de Ross, Antártida). Bol. Soc. Esp. Mineral. 21, $1-15$.

Lorimer G.W. \& Cliff G. (1976) Analytical electron microscopy of minerals. Pp. 506-519 in: Electron Microscopy in Mineralogy (H.R. Wenk, editor). Springer-Verlag, New York, USA.

Martínez-Ruiz F., Comas M.C. \& Alonso B. (1999) Mineral associations and geochemical indicators in upper Miocene to Pleistocene sediments in the Alboran basin. Proc. ODP, Sci. Results, 161, 21 -35.

Masuda H., O’Neil J.R., Jiang W.-T. \& Peacor D.R. (1996) Relation between interlayer composition of authigenic smectite, mineral assemblages, I/S reaction rates and fluid composition in silicic ash of the Nankai Trough. Clays Clay Miner. 44, 443-459.

Morata D., Puga E., Demant A. \& Aguirre L. (1997) Geochemistry and tectonic setting of the "ophites" from the External Zones of the Betic Cordilleras (S. Spain). Estudios Geol. 53, $107-120$.

Nadeau P.H., Farmer V.C., McHardy W.J. \& Bain D.C. (1985) Compositional variations of the Unterrupsroth Beidellite. Am. Miner. 70, $1004-1010$.

Nieto F., Ortega-Huertas M., Peacor D.R. \& Arostegui J. (1996) Evolution of illite/smectite from early diagenesis through incipient metamorphism in sediments of the Basque-Cantabrian Basin. Clays Clay Miner. 44, 304-323.

Portugal-Ferreira M., Morata D., Puga E., Demant A. \& Aguirre L. (1995) Evolución geoquímica y temporal del magmatismo básico Mesozoico en las Zonas Externas de las Cordilleras Béticas. Estudios Geol. 51, 109-118.

Ramseyer K. \& Boles J.R. (1986) Mixed-layer illite/ smectite minerals in Tertiary sandstones and shales, San Joaquin Basin, California. Clays Clay Miner. 34, $115-124$.

Rieder M., Cavazzini G., D’Yakonov Yu.S., FrankKamenetskii V.A., Gottardi G., Guggenheim S., Koval' P.V., Müller G., Neiva A.M.R., Radoslovich E.W., Robert J.-L., Sassi F.P., Takeda H., Weiss Z. \& Wones D.R. (1999) Nomenclature of the micas. Mineral. Mag. 63, 267-79.

Sánchez-Navas A., Martín-Algarra A. \& Nieto F. (1998) Bacterially-mediated authigenesis of clays in phosphate stromatolites. Sedimentology, 45, 519-533.

Shau Y.-H. \& Peacor D.R. (1992) Phyllosilicates in hydrothermally altered basalts from DSDP Hole 504B, Leg 83-A TEM and AEM study. Contrib. Mineral. Pet. 112, $119-133$.

Shau Y.-H., Feather M.E., Essene E.J. \& Peacor D.R. (1991) Genesis and solvus relation of submicrosco- 
pically intergrown paragonite and phengite in a blueschist from northern California. Contrib. Mineral. Pet. 106, $367-378$.

Singh B. \& Gilkes R.J. (1991) A potassium-rich beidellite from a laterite pallid zone in Western Australia. Clay Miner. 26, 233 -244.

Środoń J., Morgan D.J., Eslinger E.V., Eberl D.D. \& Karlinger M.R. (1986) Chemistry of illite/smectite and end-member illite. Clays Clay Miner. 34,
$368-378$.

Velilla N.S. (1983) Los granates del complejo de Sierra Nevada (Cordillera Bética). Ph.D. thesis, Univ. Granada, Spain.

Yau Y.-C., Peacor D.R., Essene E.J., Lee J.H., Kuo L.C. \& Cosca M.A. (1987) Hydrothermal treatment of smectite, illite, and basalt to $460^{\circ} \mathrm{C}$ : Comparison of natural with hydrothermally formed clay minerals. Clays Clay Miner. 35, 241-250. 